\title{
Good Governance, Human Rights and Social Welfare: an Evaluation
}

\author{
Nik Ahmad Kamal bin Nik Mahmod \\ International Islamic University \\ Malaysia \\ nahmad@iium.edu.my
}

\begin{abstract}
Good governance is an essential element in upholding human rights principle in a nation. Achieving social welfare and social justice via good governance in the implementation of human rights is a big challenge in developing and underdeveloped countries. The goals of social welfare are pertinent to ensure fair and just community and nation. The paper attempts to evaluate the interlinking between these three huge concepts and measures to be taken by nation states to reach the goals of the community and personal peace and development.
\end{abstract}

Keywords-Good Governance; Human Rights; Social Welfare; Justice; Development;

\section{INTRODUCTION}

Good governance is often said to be the process that has fulfilled or is by specific characteristics deemed appropriate standard recognised and accepted by international bodies such as the United Nations (UN). While defining "governance", the United Nations Economic and Social Commission for Asia and the Pacific (UNESCAP) listed eight (8) characteristics. These include accountability, transparency, the rule of law, responsiveness, equity and inclusiveness, effectiveness and efficiency and participatory.

What are human rights? Adopting the UN Human Rights, Office of the High Commissioner (OHCHR),

"Human rights are rights inherent to all human beings, whatever our nationality, place of residence, sex, national or ethnic origin, colour, religion, language, or any other status. We are all equally entitled to our human rights without discrimination. These rights are all interrelated, interdependent and indivisible".

Domestic law, international treaties, and customary international law determine human rights standards by laying down obligations of Governments to act in specific ways or to refrain from particular acts, to promote and protect human rights and fundamental freedoms of individuals or groups. The Universal Declaration of Human Rights (UDHR) governs the main principles of human rights set out by the UN in 1948 , and it is the mother of all human rights standards. Specific covenant such as the Covenant on the Civil and Political Rights and other minor conventions support the UDHR.

How does international human rights law work? Unlike state constitution and municipal law, international law will apply only if the state has assumed obligation under it through the endorsement of such rule or becoming members of the international treaties. Thus, state that has adopted the agreements is obliged to take affirmative action to put into place "domestic measures and legislation compatible with their treaty obligations and duties" (OHCHR). It is the domestic legislation that provides these rights, and it is the local enforcement of the law that ensures the international standards adopted are implemented and applied in the state. At the global and regional levels, there could also be assistance to the country in the interpretation and mechanism to ensure effective and efficient methods of these rights. There are also human rights activists through their association and society that carry out promotion, evaluation and monitoring of human rights violation throughout the world. The Civil society such as OXFAM, Human Rights Watch and Amnesty International are well-known players and very much respected by friends and foe. Their contribution to enhancing and improving human rights protection has been very significant in strengthening human rights conventions.

What is social welfare? The dictionaries have described two kinds of definitions; the functional ones refer to the welfare system as per Cambridge Dictionary's definition that regards it as the various social services provided by a state or private organisations to help poor, ill, or old people. It is also according to Collins Dictionary, the welfare of society, especially those segments of society that are underprivileged or disadvantaged because of poverty, poor education, unemployment etc. Social welfare as a condition fulfils the material, spiritual and social needs of citizens and social welfare as an organised activity in the form of social services that includes rehabilitation, social security, social empowerment and social protection (Suharto, 2009). Different countries define welfare goals differently, and they have developed distinct regimes, or set policies and institutions, for meeting these goals (Esping-Anderson, 1990). It varies from the minimalist approach of Anglo-Saxon countries to the 
social-democratic focus of Nordic societies (Esping-Anderson, 1990).

Casimir and Samuel (2015) have referred to the United Nations 1967 definition of social welfare as:

"Social welfare as an organised function is regarded as a body of activities designed to enable individuals, families, groups and communities to cope with the social problems of changing conditions. But in addition to and extending beyond the range of its responsibilities for specific services, social welfare has a further function within the broad area of a country's social development. In this larger sense, social welfare should play a major role in contributing to the effective mobilisation and deployment of human and material resources of the country to deal successfully with the social requirements of change, thereby participating in nation-building."

The learned writers than referred to the Hong Kong Government 1965 White Paper defined social welfare as:

"Social welfare services, in common with education, medical, housing and other parallel services, form a part of the social services which most developed communities have come to require and expect ... Social welfare services are required by those who are not capable without help and support of standing on their own feet as fully independent or "self-directing" members of the community. "Used in its broadest sense the term "social welfare" can embrace all efforts aimed at improving health, education, employment, housing, recreational and cultural services for the community at large. However, for the purpose of the White Paper, "social welfare" will be used in a narrower sense as the range of services provided by Social Welfare Department and the voluntary welfare sector" (1979).

Thus, social welfare demands a system to deal with the welfare of the people especially the section of the society that needs assistance to survive in their inability to provide on their own the necessities of life such as food, suitable accommodation, and primary education. Casimir and Samuel rightly concluded that "social welfare embraces laws, programmes, benefits and services which address social needs accepted as essential to the well-being of society" and "seeking for sustainable solutions" (Casimir and Samuel, 2015).

\section{GOOD GOVERNANCE AND HUMAN RIGHTS}

The meaning of good governance is not exhaustive. Nonetheless, there are common elements agreed upon by many. The Seminar on Good Governance Practices for the Promotion of Human Rights held in Seoul, the Republic of Korea in 2004 identified common elements of good governance, namely participation, accountability, transparency, responsibility of the state and accessibility, especially to the marginalised groups. The Conference has identified linkages between good governance, human rights, poverty reduction and inequalities. The conference has also emphasised on the need to widen the scope of democracy from just merely electoral freedom to the fulfilment of the people's obligation for social welfare. In the words of the Chairman of the Conference:

"Conflict and post-conflict settings pose a particular challenge to good governance; affected countries called on the international community to help to provide the know-how to implement good governance for human rights. Good governance also needs to aim for justice. While the element of the rule of law is critical as part of good governance for the promotion of human rights, that element should not merely imply respect for national law but rather for law which is consistent with the international human rights framework, with channels to promote justice." (Emphasis added).

It is common to have a scenario where domestic law does not sufficiently address the standards of an international law and human rights law due to the fact that the state has not ratified an international treaty, or the state has not been legislated by the international agreement that the country has endorsed. How then to strike a balance between domestic standards and international standards?

The debate goes on as to whether the 'doctrine of incorporation' or the 'doctrine of transformation' applies vis-àvis as to whether international law is automatically applied in a nation-state and become part of parcel of the state's municipal law. It rests by and large on the theory of 'monism' and the theory of 'dualism'. (Hamid, 2006, p.1) submits that;

"it means that according to monism, international law and municipal law are part of the same legal order and this is reflected by the fact that international law is automatically incorporated into municipal law. Conversely, under dualism, municipal law are two separate systems of law operating in its area of competence."

In the case of Malaysia, which doctrine applies depends heavily on the written Constitution. Article 74(1) of the Constitution states that Parliament has the power to make law by the legislative list enumerated in the Schedule and in this respect, the Ninth Schedule of the Constitution lays down the Federal list upon which Parliament may make law accordingly. The Federal list provides for matters of international agreement and treaties, international conventions and their implementations. Thus, only Parliament can exercise power pertains to international law. Article 39 states that the executive authority of the Federation is vested with the Yang di-Pertuan Agong (the King) and is exercisable by the prime minister and his cabinet. It is the executive that exercises executive power based on legislation made by Parliament. In the case of international agreement, treaties, and conventions, it is the executive that will enter into such agreement and on whom the responsibility to implement them (Hamid, 2006).

The practice in Malaysia is like in the United Kingdom in which the power to enter any treaty and agreement belongs to the Executive, while the ability to legally affect the agreement 
and convention by way of municipal law belongs to Parliament. Nonetheless, some treaties need not operate by a municipal law but if any treaty that affects personal rights and freedom does require an Act of Parliament for its enforcement (Hamid, 2006). Thus, it appears that in Malaysia the 'doctrine of transformation applies.

As far as customary international law is concerned, Hamid submits that the Malaysian court had applied customary international law when the occasion arose through the medium of the English common law. The courts in Malaysia may enforce common law of England by the conditions laid down in the Civil Law Act 1956. Among others, the common law must be in existence before specific dates enumerated in the Act and also subject to that there is no written law on the matter, and it is not contrary and suitable with local custom and conditions (Hamid, 2006). In Olofsen v Government of Malaysia (1966), the court decided that the rule of international law relating to immunity of a sovereign State from judicial process of a foreign country is applicable in Malaysia and the court does not have jurisdiction to entertain any action against other sovereign government. However, in the case of Public Prosecutor $v$ Narogne Sookpavit (1987), the court has refused to apply the customary international law of the right of innocent passage and relied on the applicability of the municipal law for illegal fishing.

I have addressed elsewhere in good governance and the rule of law. They are very compatible partners without which none can be implemented efficiently. Without good governance rule of law will collapse and without rule of law, good governance will never be conducted efficiently. The Conference has also raised the issue of corruption, which accordingly already addressed by practically all countries in the world through their domestic legislation. In fact, corruption is the root of the problem, and it is the primary enemy of good governance and the rule of law. The enactment of international treaties in recent years to promote international cooperation against corruption, such as the UN Convention Against Transnational Organised Crime and the UN Convention Against Corruption would undoubtedly bring the fight against corruption and money laundering to a new height at the international level.

Establishing Human Rights Commission has been the trend in most countries in Asia particularly after the 19971998 economic crisis. Malaysia has introduced its own Human Rights Commission in 1999 (Mahmod, 2013). It is called the Human Rights Commission of Malaysia (SUHAKAM) under the Human Rights Commission of Malaysia Act 1997 (SUHAKAM, 2017). In section 4, it serves to promote awareness about human rights; to inquire on human rights abuse; to advise the government on legislation that affects human rights; to advise the government on legislation that affects human rights; to advise the government on subscribing to relevant international convention on human rights and to recommend for action against person and institution for human rights abuse.

The fundamental question to such commission is the extent to which it has the power to enforce breach of human rights and travesty of human rights justice. "How independent are the body and the extent to which that they are not in consonant with any political party and cohort with the government of the day?" (Mahmod, 2015). It is crucial that any human rights commission must not be a toothless tiger and has become the tool of the ruling power in achieving their political ends. With many countries in Asia have established constitutional court as the highest judicial body to uphold human rights, Malaysia should seriously consider to have the same, not only to deal with constitutional issues but also to become the platform to deal with all actions that have affected human rights.

Established human rights standards whether in the municipal law context or the international law spheres would not be successfully implemented if there is lacking in good governance. The postulates of the rule of law in good governance by Lord Bingham and the International Bar Association (Kirby, 2010) could perhaps guide us through the process:

\begin{tabular}{|c|c|}
\hline Good Governance & Rule of Law Postulates \\
\hline Accountability & $\begin{array}{l}\text { 1. Ministers and officials exercise } \\
\text { their power reasonably within the ambit } \\
\& \text { scope of powers conferred. } \\
\text { 2. Fair and independent judicial \& } \\
\text { adjudicative system. }\end{array}$ \\
\hline Transparency & $\begin{array}{l}\text { 1. The accessibility of law } \\
\text { 2. Law decides on legal rights \& } \\
\text { not through discretionary power } \\
\text { 3. Fair exercise of adjudicatory } \\
\text { power }\end{array}$ \\
\hline Responsive & $\begin{array}{l}\text { 1. Law decides on legal rights } \& \\
\text { not through discretionary power }\end{array}$ \\
\hline Equitable \& inclusive & $\begin{array}{l}\text { 1. Law applies equally to all } \\
\text { subject to doctrine of rational } \\
\text { classification } \\
\text { 2. Ministers \& officials shall act } \\
\text { reasonably \& in good faith \& shall not } \\
\text { act ultra vires the power }\end{array}$ \\
\hline Effective \& efficient & $\begin{array}{l}\text { 1. Access to justice must be } \\
\text { assisted to those who can't afford } \\
\text { justice \& has bona fide dispute to } \\
\text { resolve }\end{array}$ \\
\hline Participatory & $\begin{array}{l}\text { 1. Conduct of governance is } \\
\text { transparent in institutions and procedure } \\
\text { together with opportunity to voice out } \\
\text { opinions }\end{array}$ \\
\hline
\end{tabular}

\section{HUMAN RIGHTS AND SOCIAL WELFARE}

One of the UDHR's preamble states,

"Whereas the peoples of the United Nations have in the Charter reaffirmed their faith in fundamental human rights, the dignity and worth of the human person and the equal rights of men and women and had determined to promote social progress and better standards of life in larger freedom." 
Further and detailed standards on social welfare include right to social security (article 22), right and freedom to work (article 23), right to rest and leisure (article 24), the right to adequate standard of living for the health and well-being of himself and of his family (article 25), right to education (article 26), right to participate in the cultural life, and the right to the protection of the moral and material interest (article 27).

The International Covenant on Economic, Social and Cultural Rights (ICESCR) further emphasized the right of social welfare, a covenant open to signature, ratification and accession by General Assembly resolution in 1966. The right to social security in article 9, assistance and protection to family life and children in article 10, adequate standard of living in article 11 that covers sufficient food, clothing and housing, and continuous improvement to living conditions. The right includes right of everyone to be free from hunger. Article 12 provides the right to physical and mental health; and the right to education in article 13. Article 15 states the right to take part in cultural life; to enjoy the benefits of scientific progress and the protection of the moral and material interests.

There is no doubt about the importance of economic and social rights. As the OCHR has observed, "they reflect genuine human needs that every state must attend to, within existing resources, in the interest of all those committed to their care". The UN recognizes that not all states are capable of fulfilling their obligations under the Conventions and the UDHR also imposes constraints on the allocation of such resources as there are. It emphasizes that;

"The Commission believes that the UDHR (and the International Covenant on Economic, Social and Cultural Rights (ICESCR)) should be read as endorsing an ongoing global conversation about what the minimum provision should be and a rule of progress to the effect that the human rights framework calls for steps to improve the position of everyone, including the least advantaged in society."

What are the issues involved in the implementation of these rights? What if the state has not ratified the convention and the state's constitution have no express provisions on economic and social rights? Malaysia, for instance, has not adopted ICESCR. Malaysia's Constitution on the chapters of fundamental liberties does not have specific provisions on economic, social and cultural rights. The Constitution does provide for the freedom of religion (article 3 and 11), the right to education (article 12) and the right to property in article 13. In the absence of express constitutional provisions, it becomes a moral and political obligation for the government to carry out measures to deal with social welfare needs of the people. Thus, its fiscal policy must address the wholesome social and welfare needs.
IV. Challenges to GOOD GOVERnANCE, HUMAN RIGHTS AND SOCIAL WELFARE

\section{A. Patronage}

Peter Blunt (Blunt, 2012) in his research about patronage wrote:

"Patronage has various guises (such as clientelism, patrimonialism, neo-patrimonialism) is fundamental 'a distinct mode of regulating crucial aspects of institutional order: the structuring of the flow of resources, exchange and power relations and their legitimation in society' (Eisenstadt and Roninger,1980, p. 49). Its structure is always based on vertical dyadic ties between patrons and clients and along which exchanges are made between the individuals concerned. However, the dy adic ties are always asymmetrical in terms of power with the patron exercising dominance through control of the most desired resources.",

It is a difficult challenge to deal with in many countries because it has become a deep-rooted practice cutting across the civil service system in many nations. The government in developing countries has been a fertile ground for patronage (Blunt). "Its practitioners have transferred basic principles and practices from earlier times and molded them to suit their particularistic interests in state institutions and organizations that are supposedly guided by Weberian rationalism."(Blunt, 2012). Blunt referred to Khan (2005, p.714) who pointed out that "the core element of the new patronage is the 'personalization of power', a traditional legacy, but the novel element is that 'the state is treated as an extension of the property of the leader, and the leader rules with the help of clients who get a pay-off for their support."

Blunt has also referred to Grindle (2010, p. 3) who observed that "the patron, occupying a strategic location in the state, is able to develop multiple links with clients within and outside of the state to form pyramidal structures of informal contractual relations that facilitate the acquisition, maintenance and extension of power 'over a country, a government, an organization, a party or a faction"”.

Blunt was conducting a study in the field of human resource management in Indonesia. He discovered that in "the field of HRM, with political and bureaucratic patrons using control over recruitment, placement, transfer and promotion as the means to gain private benefit from public resources" (Blunt, 2012). Patronage system, according to Blunt has not confined to the recruitment process; it has entered into other HRM areas such as staff placement, promotion and transfer.

The negative consequences of the patronage system are tremendous. Blunt has discovered that respondents to this study have acknowledged that the adverse effects of the patronage practices that include, it could lead to staff who were not technically competent to carry out their tasks; placement of personnel in favored locations led to distortions in the distribution of staff that led to inequity in the availability of services such as health service, and promotions were similarly influenced by patronage and its associated corrupt behavior. As rightly put by Blunt (2012): 
"From an economic perspective, the HRM patronage we have described in education and health services leads to the sacrifice of efficiency and effectiveness to the service of self-interest. The wrong people are recruited, placed, promoted and transferred for the wrong reasons-not always and not everybody but in enough cases to have a deleterious effect on the operating processes, cultures and outputs of organizations.

From the perspective of the role of the civil service in a democratic government, patronage will destroy the fundamental structure of the service itself. For countries that have adopted the British Westminster system, the civil service serves the government of the day with loyalty irrespective the colour of the government. The civil service is to carry out all policies and directives without fear or favour. If patronage has affected the civil service neutrality, discrimination and favoritism will continue. Blunt referred to Sen's (1999, p. 36) instrumental freedoms that are complementary and contribute to the general capability of a person to live more freely and submitted three of the instrumental freedoms are adversely affected by patronage, namely; political freedoms are affected in that patronage makes criticism and freedom of expression difficult if not impossible for public servants. Secondly, patronage has a negative effect on the arrangements that society makes for education, health care and other social welfare amenities (Blunt, 2012). Thirdly, patronage makes guarantee for the freedom of transparency an anathema because transparency assures openness, disclosure and lucidity when dealing with each other (Blunt).

Undoubtedly, a single prong strategy to deal with patronage will not be sufficient. Blunt has referred to Rosser et al. (2011) who suggested a political solution to patronage. Blunt, on the other hand, suggested a multi-strategies approach namely, prevention strategies that reduce the opportunities for corrupt patron-client behaviour; enforcement strategies focusing on detection and punishment; public awareness measures that promote intolerance of corruption; and building institutions that can and do efficiently address corruption (Blunt, 2012)

\section{REFERENCES}

[1] G. Eason, B. Noble, and I.N. Sneddon, "On certain integrals of Lipschitz-Hankel type involving products of Bessel functions," Phil. Trans. Roy. Soc. London, vol. A247, pp. 529-551, April 1955. (references)

[2] J. Clerk Maxwell, A Treatise on Electricity and Magnetism, 3rd ed., vol. 2. Oxford: Clarendon, 1892, pp.68-73.

[3] I.S. Jacobs and C.P. Bean, "Fine particles, thin films and exchange anisotropy," in Magnetism, vol. III, G.T. Rado and H. Suhl, Eds. New York: Academic, 1963, pp. 271-350.

[4] K. Elissa, "Title of paper if known," unpublished.

[5] R. Nicole, "Title of paper with only first word capitalized," J. Name Stand. Abbrev., in press.

[6] Y. Yorozu, M. Hirano, K. Oka, and Y. Tagawa, "Electron spectroscopy studies on magneto-optical media and plastic substrate interface," IEEE Transl. J. Magn. Japan, vol. 2, pp. 740-741, August 1987 [Digests 9th Annual Conf. Magnetics Japan, p. 301, 1982].

[7] M. Young, The Technical Writer's Handbook. Mill Valley, CA: University Science, 1989. 